\title{
Perbedaan Hasil Belajar Fisika Antara Menggunakan Model Problem Based Learning dengan Model Direct Intruction pada Siswa Kelas VII SMP Negeri 14 Palu
}

\author{
Taufik Kurahman, Muhammad Ali dan Marungkil Pasaribu \\ Email : taufik.kurahman1991@gmail.com \\ Program Studi Pendidikan Fisika FKIP Universitas Tadulako \\ Jl. Soekarno Hatta Km. 9 Kampus Bumi Tadulako Tondo Palu - Sulawesi Tengah
}

\begin{abstract}
Penelitian ini bertujuan untuk mengetahui ada tidaknya perbedaan hasil belajar fisika antara menggunakan model Problem Based Learning dengan model Direct Intruction pada siswa kelas VII SMP Negeri 14 Palu. Jenis penelitian yang digunakan adalah kuasi eksperimen dengan desain "The Non Equivalen Pretest-Posttest Design". Sampel dipilih dengan menggunakan teknik "purposive sampling", dimana kelas VII B $^{2}$ dengan jumlah siswa sebanyak 23 orang sebagai kelas eksperimen pertama dan kelas VII B $^{3}$ dengan jumlah siswa sebanyak 22 orang sebagai kelas eksperimen kedua. Instrumen yang digunakan berupa tes hasil belajar fisika dalam bentuk pilihan ganda. Berdasarkan hasil analisis data pretest, kelas eksperimen pertama memperoleh skor rata-rata sebesar 5,89 dengan standar deviasi sebesar 2,04, sedangkan kelas eksperimen kedua memperoleh skor rata-rata sebesar 5,86 dengan standar deviasi sebesar 1,99. Hasil uji kesamaan dua rata-rata menunjukan bahwa sebelum diberi perlakuan tidak terdapat perbedaan hasil belajar fisika antara kelas eksperimen pertama dan kelas eksperimen kedua. Sedangkan berdasarkan hasil analisis data posttest, kelas eksperimen pertama memperoleh skor rata-rata sebesar 15,89 dengan standar deviasi sebesar 2,24, sedangkan kelas eksperimen kedua memperoleh skor rata-rata sebesar 13,95 dengan standar deviasi sebesar 2,13. Hasil pengujian hipotesis diperoleh nilai $t_{\text {hitung }}(2,985)>t_{\text {tabel }}(2,017)$. Hal ini menunjukan bahwa terdapat perbedaan hasil belajar fisika antara menggunakan model Problem Based Learning dengan model Direct Intruction pada siswa kelas VII SMP Negeri 14 Palu. Terdapatnya perbedaan hasil belajar fisika antara kelas eksperimen pertama dan kelas eksperimen kedua diduga karena antara model Problem Based Learning dan model Direct Intruction memiliki proses atau tahap pembelajaran yang berbeda.
\end{abstract}

Kata kunci : Model Problem Based Learning, Model Direct Intruction, Hasil Belajar Fisika.

\section{PENDAHULUAN}

Pendidikan merupakan aspek yang sangat penting bagi kehidupan dan merupakan salah satu faktor yang sangat menunjang dalam kemajuan suatu bangsa. Keberhasilan suatu pendidikan dapat diukur dengan pencapaian hasil belajar siswa. Dengan hasil belajar yang dicapai siswa dapat diketahui sejauh mana keberhasilan siswa menguasai materi yang diajarkan oleh guru.

Prestasi hasil belajar siswa dipengaruhi oleh tiga faktor, yaitu faktor internal (faktor yang bersumber pada diri siswa), faktor eksternal (faktor yang bersumber dari luar diri siswa) dan faktor pendekatan pembelajaran yang meliputi strategi, model dan metode yang digunakan dalam proses pembelajaran ${ }^{[1]}$.

Begitu pula dalam pembelajaran fisika, selain faktor dari diri siswa penerapan model pembelajaran yang efektif begitu sangat penting untuk memaksimalkan hasil belajar fisika siswa. Karena dalam belajar fisika siswa tidak cukup hannya dengan mengingat atau menghafal materi yang diajarkan, namun siswa diharapkan dapat memahami, menganalisis dan mampu memecahkan masalah dalam fisika.

Mengatasi permasalahan di atas guru fisika diharapkan dapat memilih model pembelajaran yang tepat yang dapat meningkatkan kemampuan siswa dalam memahami, menganalisis dan mampu memecahkan masalah dalam fisika.

Dewasa ini banyak model pembelajaran yang kita ketahui yang begitu efektif digunakan untuk memaksimalkan hasil belajar fisika, diataranya dengan menerapkan model Problem Based Learning dan model Direct Instruction. Selama ini sudah banyak penelitian yang membuktikan keefektifan kedua model pembelajaran tersebut dalam memaksimalkan hasil belajar fisika.

Model Problem Based Learning dan model Direct Instruction keduanya memiliki keriteria pembelajaran yang berbeda. Model Problem Based Learning merupakan model pembelajaran yang menghadapkan siswa pada masalah dunia nyata, sehingga siswa dapat menyusun pengetahuannya sendiri, menumbuh 
kembangkan keterampilan yang tinggi bagi siswa, memandirikan siwa dan meningkatkan kepercayaan diri pada siswa ${ }^{[2]}$. Peran guru pada model Problem Based Learning adalah mengajukan masalah, mengajukan pertanyaan, memberikan suasana yang mudah dalam berdialog, memberikan fasilitas penelitian dan membimbing penelitian ${ }^{[2]}$.

Sedangkan model Direct Instruction dirancang secara khusus untuk mempromosikan belajar siswa dengan pengetahuan prosedural dan pengetahuan deklaratif yang terstruktur dengan baik dan dapat diajarkan secara selangkah demi selangkah [3]. Model Direct Instruction merupakan model pembelajaran yang berpusat pada guru, yang mempunyai lima langkah dalam pelaksanaannya, yaitu menyiapkan siswa menerima pelajaran, demontrasi, pelatihan terbimbing, umpan balik dan pelatihan mandiri ${ }^{[3]}$.

Berdasarkan uraian di atas, maka peneliti bermaksud melakukuan penelitian untuk mengetahui ada tidaknya perbedaan hasil belajar fisika antara menggunakan model Problem Based Learning dengan model Direct Intruction pada siswa kelas VII SMP Negeri 14 Palu.

\section{METODE PENELITIAN}

Jenis penelitian ini merupakan penelitian kuantitatif yang menggunakan metode penelitian kuasi eksperimen dan degan menggunakan desain penelitian "The Non Equivalen Pretest-Postest Desigen". Dalam desain ini terdapat dua kelompok eksperimen yang akan diberi perlakuan yang berbeda. Adapun desainnya dapat dilihat pada tabel 1 berikut ${ }^{[4]}$.

Tabel 1. Desain Penelitian : The Non ekuivalen pretest-posttest design

\begin{tabular}{cccc}
\hline $\begin{array}{c}\text { Kelas } \\
\text { Eksperimen }\end{array}$ & $\begin{array}{c}\text { Tes } \\
\text { Awal }\end{array}$ & Perlakuan & $\begin{array}{c}\text { Tes } \\
\text { Akhir }\end{array}$ \\
\hline $\begin{array}{c}\text { Pertama } \\
\text { Kedua }\end{array}$ & $\mathrm{O}$ & $\mathrm{X}_{1}$ & $\mathrm{O}$ \\
& $\mathrm{O}$ & $\mathrm{X}_{2}$ & $\mathrm{O}$ \\
\hline
\end{tabular}

Keterangan:

$\mathrm{X}_{1}=$ Perlakuan untuk kelas eksperimen pertama dengan menerapkan model Problem Based Learning.

$\mathrm{X}_{2}=$ Perlakuan untuk kelas eksperimen kedua dengan menerapkan model Direct Intruction.

$\mathrm{O}=$ Tes awal dan tes akhir.

Penelitian ini dilaksanakan di sekolah SMP Negeri 14 Palu pada semester genap Tahun ajaran 2015/2016. Sampel dalam penelitian ini dipilih dengan cara "Purposive Sampling", yaitu dengan pertimbangan dan ketentuan dari guru mata pelajaran IPA Terpadu pada kelas VII SMP Negeri 14 Palu. Kedua kelas yang akan dipilih menjadi sampel merupakan kelas yang siswanya dianggap homogen secara akademik. Kelas yang dijadikan sampel dalam penelitian ini adalah kelas VII $\mathrm{B}^{2}$ sebagai kelompok kelas eksperimen pertama yang akan menerapkan model Problem Based Learning dan kelas VII $\mathrm{B}^{3}$ sebagai kelompok kelas eksperimen kedua yang menerapkan model Direct Intruction.

Penelitian ini menggunakan instrumen berupa tes hasil belajar fisika dalam bentuk pilihan ganda sebanyak 20 butir soal. Setiap butir soal telah divalidasi oleh validator ahli dan juga telah diuji cobakan untuk mengetahui tingkat validitas, tingkat kesukaran, tingkat daya pembeda dan juga tingkat reliabelitas butir soal.

Jenis data yang diperoleh dalam penelitian ini yaitu berupa data primer yang bersumber dari hasil pretest dan posttest yang diberikan kepada klompok siswa kelas eksperimen pertama dan juga kelompok siswa kelas eksperimen kedua. tes yang digunakan pada tes awal sama dengan tes akhir.

\section{HASIL DAN PEMBAHASAN}

Data yang diperoleh dalam penelitian ini berupa skor pretest dan posttest hasil belajar fisika dari kelas eksperimen pertama (VII $\mathrm{B}^{2}$ ) dan kelas eksperimen kedua (VII $B^{3}$ ). Berdasarkan hasil pemberian pretest diperoleh deskripsi data hasil belajar fisika seperti pada tabel 2 berikut.

Tabel 2. Deskripsi Data Pretest Hasil Belajar Fisika

\begin{tabular}{ccc}
\hline Deskripsi & $\begin{array}{c}\text { Kelas } \\
\text { Eksperimen } \\
\text { Pertama }\end{array}$ & $\begin{array}{c}\text { Kelas } \\
\text { Eksperimen } \\
\text { Kedua }\end{array}$ \\
\hline Jumlah Siswa & 23 & 22 \\
\hline Skor Minimum & 2 & 2 \\
\hline Skor Maksimum & 10 & 11 \\
\hline Skor Total & 134 & 130 \\
\hline Skor Rata-rata & 5,89 & 5,86 \\
\hline Standar Deviasi & 2,04 & 1,99
\end{tabular}

Data hasil pretest dalam penelitian ini kemudian dilakukan uji normalitas, uji homogenitas dan uji kesamaan dua rata-rata.

Pengujian normalitas data pretest dalam penelitian ini menggunakan uji Chi-kuadrat dengan kriteria penerimaan $X^{2}$ Hitung $<X_{\text {tabel, }}^{2}$ pada taraf nyata $a=0,05$ dan derajat kebebasan $d k=k-1=5-1=4^{[5]}$. Adapun hasil uji normalitas data pretest antara kedua kelas eksperimen dapat dilihat pada tabel 3 berikut. 
Tabel 3. Hasil Uji Normalitas Tes Awal

\begin{tabular}{ccc}
\hline Uraian & \multicolumn{2}{c}{ Tes Awal } \\
\cline { 2 - 3 } & $\begin{array}{c}\text { Eksperimen } \\
\text { Pertama }\end{array}$ & $\begin{array}{c}\text { Eksperimen } \\
\text { Kedua }\end{array}$ \\
\hline Sampel & 23 & 22 \\
\hline$X^{2}$ hitung & 0,90 & 0,53 \\
\hline$X^{2}$ tabel & \multicolumn{2}{c}{9,49} \\
\hline Keterangan & \multicolumn{2}{c}{ Terdistribusi Normal } \\
\hline
\end{tabular}

Berdasarkan tabel 3, untuk kelas eksperimen pertama diperoleh nilai $X^{2}$ hitung $=0,90<X_{\text {tabel }}^{2}=$ 9,49 , dan kelas eksperimen kedua juga diperoleh nilai $X^{2}$ hitung $=0,53<X_{\text {tabel }}^{2}=9,49$. Sehingga dapat disimpulkan bahwa skor yang diperoleh dari tes awl pada kelas eksperimen pertama maupun kelas eksperimen kedua berdistribusi dengan normal.

Pengujian homogenitas data pretest dalam penelitian ini menggunakan uji $F$ dengan penerimaan hipotesis $H_{0}$ jika $F_{(1-a)(n 1-1)}<F_{\text {hitung }}<$ $F_{1 / 2}$ a (n1-1, n2-1), dengan derajat kebebasan $d k=\mathrm{k}-1=5-1=4$, pada taraf nyata $a=$ $0,05^{[5]}$. Perolehan hasil pengujian homogenitas skor tes awal pada kelas eksperimen pertama dan kelas eksperimen kedua dapat dilihat pada tabel 4 berikut.

Tabel 4. Hasil Uji Homogenitas Tes Awal

\begin{tabular}{lll}
\hline \multirow{2}{*}{ Uraian } & \multicolumn{2}{l}{ Kelas Eksperimen } \\
\cline { 2 - 3 } & Pertama & Kedua \\
\hline Nilai Varians & 4,16 & 3,96 \\
\hline Nilai $F_{\text {hitung }}$ & 1,05 & \\
\hline Nilai $F_{(1-a)(n 1-1)}$ & 0,49 & \\
\hline Nilai $F_{1 / 2 a(n 1-1, n 2-1)}$ & 2,03 & \\
\hline Keputusan & Homogen & \\
\hline
\end{tabular}

Berdasarkan tabel 4, diperoleh nilai $F_{\text {hitung }}$ $(1,05)>F_{0,95(22,23)}(0,49)$ dan $F_{\text {hitung }}(1,05)<$ $F_{0,05(23,22)}(2,03)$. Sehingga dapat disimpulkan bahwa skor tes awal pada kelas eksperimen pertama dan kelas eksperimen kedua memiliki varians yang sama (homogen). Pengujian kesamaan dua rata- rata pretest dalam penelitian ini menggunakan $u j i-t$ dua pihak dengan kriteria pengujian $H_{0}$ diterima jika $-t_{1-0.5 a}$ $<t<t_{1-0.5 a}$ pada taraf nyata $a=0,05$ dan $d k=$ $=\left(\mathrm{n}_{1}+\mathrm{n}_{2}-2=23+22-2=43\right)$ serta untuk nilai $t$ lainnya $H_{0}$ ditolak ${ }^{[5]}$. Perolehan hasil uji kesamaan dua rata-rata (uji-t) dua pihak pada pretest dapat dilihat pada tabel 5 berikut.

Tabel 5. Hasil Uji Kesamaan Dua Rata-rat Tes Awal

\begin{tabular}{ccc}
\hline \multirow{2}{*}{ Uraian } & \multicolumn{2}{c}{ Kelas Eksperimen } \\
\cline { 2 - 3 } & Pertama & Kedua \\
\hline Nilai Rata-rata & 5,89 & 5,86 \\
\hline Standar Deviasi & 2,04 & 1,99 \\
\hline$t_{\text {hitung }}$ & \multicolumn{2}{c}{0,050} \\
\hline$t_{\text {tabel }}$ & \multicolumn{2}{c}{2,017} \\
\hline Keputusan & \multicolumn{3}{c}{$H_{0}$ Diterima } \\
\hline
\end{tabular}

Berdasarkan tabel 5 , hasil analisis uji-t dua pihak diperoleh nilai $-t_{\text {tabel }}(-2,017)>t_{\text {hitung }}$ $(0,050)<t_{\text {tabel }}(2,017)$. Hal ini menunjukan bahwa $t_{\text {hitung }}$ berada pada daerah penerimaan $H_{0}$ dan penolakan pada daerah $H_{1}$. Sehingga dapat disimpulkan bahwa sebelum diberi perlakuan tidak terdapat perbedaan hasil belajar fisika antara kelas eksperimen pertama (VII $\mathrm{B}^{2}$ ) dan kelas eksperimen kedua (VII $B^{3}$ ).

Berdasarkan hasil pemberian posttest diperoleh deskripsi data hasil belajar fisika seperti pada tabel 6 berikut.

Tabel 6. Deskripsi Data Posttest Hasil Belajar Fisika

\begin{tabular}{ccc}
\hline Deskripsi & $\begin{array}{c}\text { Kelas } \\
\text { Eksperimen } \\
\text { Pertama }\end{array}$ & $\begin{array}{c}\text { Kelas } \\
\text { Eksperimen } \\
\text { Pertama }\end{array}$ \\
\hline Jumlah Siswa & 23 & 22 \\
\hline Skor Minimum & 10 & 8 \\
\hline Skor Maksimum & 19 & 16 \\
\hline Skor Total & 361 & 297 \\
\hline Skor Rata-rata & 15.89 & 13,95 \\
\hline Standar Deviasi & 2,24 & 2,13 \\
\hline
\end{tabular}

Data hasil Posttest dalam penelitian ini kemudian dilakukan $u \mathrm{ji}$ hipotesis dengan menggunakan statistik uji-t dua pihak dengan kriteria pengujian $H_{0}$ diterima jika $-t_{1-0.5 a}<t<t_{1-0.5 a}$ pada taraf nyata $a=0,05$ dan $d k=\left(n_{1}+n_{2}-2=23+22-2=43\right)$ serta untuk nilai $t$ lainnya $H_{0}$ ditolak ${ }^{[5]}$. Perolehan hasil $u j i$ hipotesis ( $u j i-t$ ) dua pihak pada tes akhir dapat dilihat pada tabel 7 berikut.

Tabel 7. Hasil Uji Hipotesis Tes Akhir

\begin{tabular}{ccc}
\hline \multirow{2}{*}{ Uraian } & \multicolumn{2}{c}{ Kelas Eksperimen } \\
\cline { 2 - 3 } & Pertama & Kedua \\
\hline Nilai Rata-rata & 15,89 & 13,95 \\
\hline Standar Deviasi & 2,24 & 2,13 \\
\hline$t_{\text {hitung }}$ & \multicolumn{2}{c}{2,985} \\
\hline$t_{\text {tabel }}$ & \multicolumn{2}{c}{2,017} \\
\hline Keputusan & \multicolumn{2}{c}{$H_{0}$ Ditolak } \\
\hline
\end{tabular}

Berdasarkan tabel 7 , hasil analisis $u j i$ hipotesis $(u j \mathrm{i}-t)$ dua pihak diperoleh nilai $t_{\text {hitung }}(2,985)>t_{\text {tabel }}(2,017)$. Hal ini menunjukan bahwa $t_{\text {hitung }}$ berada pada daerah penolakan $H_{0}$ dan penerimaan pada daerah $H_{1}$. Sehingga dapat disimpulkan bahwa pada tes akhir terdapat perbedaan hasil belajar fisika antara kelompok siswa yang diajarkan menggunakan model Problem Based Learning dengan kelompok siswa yang diajarkan dengan menggunakan model Direct intruction.

Adanya perbedaan hasil belajar fisika yang diperoleh antara kelas eksperimen pertama dan kelas eksperimen kedua diduga karena kedua kelas tersebut diajarkan dengan menggunakan dua model pembelajaran yang berbeda. Pada kelas eksperimen pertama diajarkan dengan 
menggunakan model Problem Based Learning, sedangakan kelas eksperimen kedua diajarkan dengan menggunakan model Direct Intruction.

Antara model Problem Based Learning dan model Direct Intruction memiliki proses atau tahapan pembelajaran yang berbeda. Hal inilah diduga yang menyebabkan terdapatnya perbedaan hasil belajar fisika antara kelas VII $B^{2}$ dan VII $\mathrm{B}^{3}$. Adapun tahapan pembelajaran pada model Problem Based Learning yaitu diawali dengan orientasi siswa pada masalah dunia nyata. Contohnya siswa diberi pertanyaan "Apa yang menyebabkan es batu yang dibiarkan di tempat terbuka akan menjadi cair?". Pada saat pengajuan permasalah terjadi perdebatan antara siswa yang berbeda pendapat, stiap siswa penasaran atas jawaban yang sesungguhnya. Siswa terlihat lebih termotivasi dalam belajar fisika dan rasa ingin tahu siswa tentang materi kalor menjadi lebih besar. Selanjutnya siswa melakukan penyelidika dengan melakukan eksperimen dengan memanaskan es batu hingga mencair. Ketika siswa melakukan penyelidikan siswa dapat menjawab permasalahan yang mereka hadapi bahwa es batu mencair karna menerima kalor. Selanjutnya pada tahap akhir siswa diberi penjelasan bahwa "ketika zat diberi kalor maka zat tersebut akan mengalami perubahan suhu dan juga perubahan wujud zat". Dengan penjelasan yang siswa peroleh, siswa semakin paham dan yakin dengan konsep kalor yang dimiliki.

Sedangkan tahapan pembelajaran pada model Direct Intruction diawali dengan guru menyampaikan tujuan pembelajaran dan selanjutnya guru menjelaskan pengetahuan dengan metode ceramah tentang pengertian kalor dan pengaruh kalor terhadap suatu benda. Pada saat guru menyampaikan materi kalor nampak bahwa siswa hanya menjadi pendengar dan pengamat di dalam kelas. Pada tahap selanjutnya guru memberi latihan mandiri kepada siswa, seperti memberi pertanyaan "apa yang terjadi jika suatu zat atau benda diberi kalor?". Pada soal tersebut masih banyak siswa yang belum menjawab dengan benar. Masih banyak siswa menjawab "zat atau benda akan menjadi panas". Kurang tepatnya siswa menjawab soal pada latihan diduga disebabkan karena cara guru menyamapiakan pengetahuan tentang kalor dengan metode ceramah yang mengakibatkan siswa belum memiliki konsep kalor dengan baik.

Berdasarkan uraian-uraian di atas, jelas bahwa antara model Problem Based Learning dan model Direct Intruction memiliki tahapan pembelajaran yang berbeda dan berimbas pada hasil belajaran fisika yang diperoleh.

\section{KESIMPULAN}

Berdasarkan hasil analisis data penelitian, diperoleh skor rata-rata hasil belajar fisika untuk kelas eksperimen pertama yang menerapkan model Problem Based Learning sebesar 15,89 dengan standar deviasi sebesar 2,24, sedangkan pada kelas eksperimen kedua yang menerapkan model Direct Intruction diperoleh skor rata-rata sebesar 13,95 dengan standar deviasi sebesar 2,13 . Untuk pengujian hipotesis menggunakan uji-t pada dua pihak diperoleh nilai $t_{\text {hitung }}(2,98)>t_{\text {tabel }}(2,017)$. Hal ini menunjukan bahwa $t_{\text {hitung }}$ berada pada daerah penolakan $H_{0}$ dan penerimaan pada daerah $H_{1}$. Sehingga dapat disimpulkan bahwa terdapat perbedaan hasil belajar fisika antara kelompok siswa yang diajarkan menggunakan model Problem Based Learning dengan kelompok siswa yang diajarkan mengguakan model Direct Intruction pada siswa kelas VII SMP Negeri 14 Palu. Terdapatnya perbedaan hasil belajar fisika antara kelas eksperimen pertama dan kelas eksperimen kedua diduga karena antara model Problem Based Learning dan model Direct Intruction memiliki proses atau tahap pembelajaran yang berbeda.

\section{DAFTAR PUSTAKA}

[1] Syah, M. (2006). Psikoligi belajar. Jakarta: Raja Grafindo Persada.

[2] Trianto. (2007). Model Pembelajaran Terpadu dalam Teori dan Praktek. Jakarta: Prestasi Pustaka Publisher.

[3] Kardi dan Nur, M. (2000). Pegajaran Langsung. Pusdat Sains dan Matematika Sekolah Program Pasca Sarjana UNESA.

[4] Sugiyono, (2013). Metode Penelitian Pendidikan. Bandung: Alfabeta.

[5] Sudjana. (2005). Metode Statistika. Bandung: Tarsito. 